\title{
A Review Paper on Performance Behavior of High Volume Fly-Ash Concrete Under Elevated Temperature
}

\author{
Ashwini PG Student Transportation, Department of Civil \\ Engineering, M S Ramaiah University of Applied Sciences, \\ Bangalore, Karnataka, India.
}

\author{
Naveen Kumar HS, Assistant professor, Department of Civil \\ Engineering, M S Ramaiah University of Applied Sciences, \\ Bangalore, Karnataka, India.
}

\author{
Nikhil T R Assistant professor \\ Department of Civil Engineering M S Ramaiah University of Applied Sciences \\ Bangalore, Karnataka, India.
}

\begin{abstract}
Removal of fly ash (FA) coming about because of the burning of coal-terminated electric fire stations and nuclear power plants is one of the major natural difficulties. This test keeps on expanding with expanding the measure of FA and diminishing the limit of landfill space. Consequently, considers have been done to re-utilize high-volumes of fly ash (HVFA) as concrete substitution in development materials. This paper presents a diagram of the past investigations did on the utilization of high volume $F A$ as a fractional substitution of concrete in customary solid blends dependent on Portland concrete (PC). Crisp properties, mechanical properties, warm properties and electrical resistivity of solid blends containing HVFA as concrete substitution have been surveyed additionally depicts the an outline of the past investigations on various kinds of cement presented to changing raised temperature and their quality properties over the temperature introduction are assessed.
\end{abstract}

Keywords:- HVFA, Concrete, Temparature,

\section{INTRODUCTION}

Concrete is the most flexible development material because of its high compressive quality and mouldability. It is most generally utilized development material and assessed that it is the second most noteworthy devoured material on the planet. As the utilization of solid builds step by step, the utilization of concrete likewise increments massively. The expanding shortage of crude materials and a dire need to ensure nature against contamination has focused on the essentialness of growing new materials for development. The use of waste materials or by item from the assembling enterprises can be utilized as an incomplete substitution of concrete in concrete with no decrease on its ideal quality. Fly Ash is one of the pozzolanic materials created by consuming coal in warm force plants. It is otherwise called pounded fuel debris, container debris; smokestack debris comprises about $80 \%$ of all out debris produced in power plants. Rather than arranging this enormous measure of fly debris in land, it tends to be successfully utilized as substitution in concrete. There is a ton of extension to use the fly ash in the development of asphalts, Many research works have demonstrated that, utilization of fly ash in huge amounts in concrete confers a few focal points. The concrete with fly ash over half of cementitious material i.e. more than $50 \%$ of cementitious material by weight is viewed as 'high volume fly ash concrete'. HVFA concrete is presently getting acknowledged and utilized in numerous basic applications including structures presented to raised temperatures. These structures incorporate solid stockpiling, gasification and liquefaction vessels in metallurgical, compound, force, glass and concrete enterprises. Different structures which are presented to elevated temperature are strengthened solid smokestacks with solid dividers, atomic reactor vessels, air create motor test cells, rocket take off platforms, turbo stream runways. Not withstanding this fire mishaps happen in typical solid structures in urban mechanical zones. The materials utilized for these structures ought to be fit for opposing high temperatures.

\section{CRITICAL REVIEW ON CONCRETE BASED ON BACTERIAL SOLUTION}

M.S Khan et al. 2014 [1] . This paper examined the effect of elevated temperature on the behavior of high volume fly ash concrete. It presents the study of compressive and split tensile behavior of an ordinary concrete mix and high volume fly ash mix concrete with the replacement of cement with fly ash in the range of $40 \%$, $50 \% \& 60 \%$ by weight. The cylinders and cubes are prepared and cured for a period of 28-days and are exposed to varying peak temperature ranging from $100-900^{\circ} \mathrm{c}$ to investigate the influence of temperature on the behavior of fly ash concrete. Experimental results shows that the compressive and split tensile strength of HVFAC increased initially with increase in temperature and reached to a maximum value at about $300^{\circ} \mathrm{c}$ and also observed that the tensile and compressive strength of the concrete decreased with the increase in temperature and fly ash content.

Mahesh Tailam 2018 [2]. Paper describes the temperature studies on fly ash based concrete. It focuses on the use of concrete mixes M20 to M50 grades with 25\% of replacement of fly ash. The cubes are casted for both the mixes and cured for a period of 28 days and 56 days, than the tests are conducted to study the temperature behavior and strength properties of both the mixes. The compressive 
strength of trial concrete specimens with fly ash and without fly ash tested for age of 28 days and 56days shows that fly ash concrete gives more compressive strength than ordinary concrete. It also observed that for 26 and 56 thermal cycle @ $1000^{\circ} \mathrm{C}$ the compressive strength of Ordinary concrete shows decrease in trend and fly ash concrete shows increase in trend for some grade of concrete.

Jagadkumari.et.al 2017. [3] studied the effect of elevated temperature on compressive strength of high volume fly ash concrete. The mechanical properties of the concrete are examined for ordinary concrete and high volume fly ash concrete for a curing period 28 days and the behavior of the concrete at elevated temperatures up to 100 $800^{\circ} \mathrm{c}$ for a time period of $1 \mathrm{hr}, 2 \mathrm{hr}$, and $3 \mathrm{hr}$ are tested. The test results shows that thermal cracks were observed at temperature of $700^{\circ} \mathrm{c}$ and $800^{\circ} \mathrm{c}$ on surface of ordinary and HVFA concrete specimen and the compressive strength of all the heated specimens were less than the strength of companion cubes, and it has seen that the ordinary concrete retained more strength than HVFA concrete for 1 hour duration, However for 2 hour duration of exposure the residual strength variation is similar for both concretes. At 3hour duration of exposure HVFA concrete showed almost equal strength as ordinary concrete but HVFA concrete performed better than ordinary concrete at all temperatures.

B. BalaKrishna. 2016 [4] studied the Mechanical Properties and Thermal Resistance of High Volume Fly Ash Concrete for Energy Efficiency in Building Construction With the aim of sustainability development, high volume fly ash (HVFA) were tested in concrete by substituting 40, 50 and $60 \%$ of OPC with fly ash. The test result indicates that HVFA concrete positively influenced the workability; however, the setting times of the concrete were longer. It has been found that the development of strength of high volume fly ash concrete was relatively slower, but a higher strength development at later ages was observed in concrete containing HVFA. The performance of concrete at elevated temperatures reveals that concrete without any fly ash has better resistance than HVFA concrete at high temperature. The use of high volume fly ash concrete is, therefore, highly desirable as it has a much lower embodied energy content compared to Portland cement concrete.

B.H. Manjunath et al. 2016 [5] investigated high volume high performance fly ash concrete mix design for pavement overlay for sustainable development, the investigative studies includes the essential properties of the materials for pavement overlay which includes the compressive strength, flexural strength and modulus of elasticity. The high volume high performance fly ash concrete was designed for a M60 grade of concrete and more than $50 \%$ fly ash is used which leads to the sustainable development of the pavement overlay. The test specimens of controlled concrete and HVHPF concerte are casted to a size of $100 \times 100 \times 500 \mathrm{~mm}$ and cured for $7,14,28$ and 56 day after the curing the cubes are tested for compressive strength, flexural strength and modulus of elasticity. The experimental results shows that the addition of $60 \%$ fly ash by weight of cement has produced more strength at the end of 56 days. Hence the fly ash concrete gives more strength and the cylinders and beams are cast and tested for paving properties has improved properties.

Dr. K. V.Ramesh et.al.2016 [6] This investigation was carried on A Study on High Volume Fly Ash Concrete Exposed To Elevated Temperatures. The present study aims at investigating the performance of high volume fly ash (HVFA) concrete at elevated temperature exposed up to $800{ }^{0} \mathrm{C}$ at interval of $200{ }^{0} \mathrm{C}$ for three hours duration is investigated..The physical and mechanical properties of high volume fly ash concrete are studied. Variable of the test program includes replacement of cement with fly ash from $30 \%$ to $50 \%$, temperatures from $27{ }^{\circ} \mathrm{C}$ to $800{ }^{\circ} \mathrm{Cat}$ an interval $200{ }^{\circ} \mathrm{C}$ for 3 hours duration. The physical and mechanical properties studied are residual compressive strength, weight loss, colour change. The test results showed that the residual strength of concrete having replacements up to $50 \%$ was comparative with control concrete. Control concrete specimens showed higher weight loses when compared with fly ash concrete.

Huai-shuai shang et al 2013[7] studied the effect of elevated temperature on high performance concrete for an exposure of temperature up to a range of $20^{\circ} \mathrm{C}-500^{\circ} \mathrm{C}$. To determine the mechanical and thermal properties of M50 and M60grade concretes are designed with $20 \%$ and $21 \%$ of fly ash by weight of cement. To check the behavior of concrete compressive strength, flexural strength ,cleavage strength, and ultrasonic velocity tests are carried ,after the curing period of 28 days and also the specimens are tested for elevated temperature 20,100,200,300,400 and $500^{\circ} \mathrm{C}$. The experimental results shows the thermal properties of HPC is same as plain concrete, the compressive strength will not change at $20^{\circ} \mathrm{C}$ at $200^{\circ} \mathrm{C}$ the strength decreased by $1 \% \& 25 \%$ and at temperature of $400^{\circ} \mathrm{C}-500^{\circ} \mathrm{C}$ the HPC looses strength at faster rate. The cleavage strength at $500^{\circ} \mathrm{C}$ of $\mathrm{C} 50$ and $\mathrm{C} 60$ is about $62.2 \%$ and $65.2 \%$ of the original strength (at $20^{\circ} \mathrm{C}$ ).

Chung-Ho Huang et al.2013 [8]. The present study was undertaken to establish the mechanical properties of concrete containing high volume fly ash. The mix design was developed for concrete with $20-80 \%$ of fly ash replacement by weight of cement. In the study the tests are conducted for fresh and hardened concrete. The compressive and flexural strength of HVFA concrete were demonstrated at the late age of 91days \& 365 days. The experimental studies shows Concrete containing fly ash of up to $80 \%$ of cementations material content can be proportioned to have adequate workability when a more suitable Super Plasticizer is used and The early compressive strength gain of the control concrete without fly ash was superior to that of the fly-ash concretes, and also observed a significant strength gain from 7 to 28 days and from 28 to $56,91,182$, and 365 days for the concrete containing high volumes of fly ash. 
Metin Husem.et.al 2005[9]. The experimental studies are carried on the effect of high temperature on compressive and flexural strength of ordinary and high performance concrete. The tests were carried on the concrete by incorporating micro-concrete into the mixes. The compressive and flexural strength of the ordinary and HPC were determined and the micro-concrete is incorporated for thermal testing to study the effect of high temperature on compressive and flexural strength of the concrete. The temperature range of $200^{\circ} \mathrm{C}-1000^{\circ} \mathrm{C}$ with an interval of $200^{\circ} \mathrm{C}$. The test specimens are casted, cured and cooled differently in air and water. Experimental results shows for ordinary concrete strength decreases with an increase in temperature compared to the high performance microconcrete. And it also observed that the type of cooling(air or water) affects the residual compressive and flexural strength at elevated temperature, the compressive strength gain of specimens is $13 \%$ for cooling in air and $5 \%$ for cooling in water. The compressive and flexural strength of HPMC cooled in air \& water decreased up to $200^{\circ} \mathrm{C}$ and increased from $200-400^{\circ} \mathrm{C}$, whereas for OMC(ordinary micro concrete) it decreases continuously.

T.S. Ramesh Babu 2016 [10]. The paper presents the study of effect of natural admixture(NAD) on the compressive, split tensile strength, and modulus of elasticity of conventional concrete(CC) and high volume fly ash concrete(HVFAC), the research undergoes with the replacement cementitious material by of $0 \%-55 \%(0 \% 25 \%$ $35 \% 45 \% 55 \%$ ) fly ash for a M25-garde of concrete by using a broilers hens egg as a natural admixture. The tested NAD dosages of $(0 \%, 0.25 \%, 0.5 \%, \& 0.75 \%)$. The fresh properties of the binder are tested for varying dosage of NAD, for the initial setting time addition $0.25 \%$ of NAD shows rapid hardening for all mixes hence the setting time is very less due to that the slump loss was observed @ $0.25 \%$ and it is considered as optimum dosage. It has also observed that concrete mixes with $35 \%$ of fly ash and $0.25 \%$ of NAD have attained higher compressive strength value at later ages and for $55 \%$ of fly ash blended mix attained the desired strength at 28 days with $0.25 \%$ NAD and the split tensile strength and modulus of elasticity follows the same trend as like compressive strength.

Nikhil T.R 2019 [11]. The investigation undergoes the study of use of high volume fly ash in concrete pavement for sustainable development. The research has been carried on the utilization of the nuclear waste fly ash to use as a material for pavement construction here an attempt is made to use the HVFA concrete of up to $50 \%$ of cement is replaced by FA by designing concrete mixture for M40 grade. The designed concrete for pavement is being evaluated for the compressive strength, flexural strength and modulus of elasticity and the economic design thickness of pavement and cost comparison of different types of pavements are evaluated. The experimental results shows The Flexural Strength of High Volume Fly Ash Concrete increases by $6.27 \%$ at 90 days curing when compared to Controlled Concrete at 28 days curing. Hence HVFAC can be used for construction of new pavements only and not for overlay. And Due to higher flexural strength there will be reduction in thickness of pavements and hence High Volume Fly Ash Concrete pavements are more economical.

Mr.A.Gunaseelan. et al. 2016 [12] discussed about the experimental study on performance of high volume fly ash concrete. presents the results of an experimental investigation dealing with concrete incorporating high volumes of Class F fly ash. Portland cement was replaced with three percentages $(40 \%, 45 \%$, and $50 \%)$ of Class F fly ash Tests were performed for fresh concrete properties: slump, air content, unit weight, and temperature. Compressive, splitting tensile and flexural strengths were determined up to 28 days of testing. Test results indicated that the use of high volumes of Class F fly ash as a partial replacement of cement in concrete decreased its 28-day compressive, splitting tensile strength and flexural strengths of the concrete. Based on the test results, it was concluded that Class F fly ash can be suitably used up to $50 \%$ level of cement replacement in concrete for use in precast elements and reinforced cement concrete construction.

Cengiz Duran. 2001 [13]. The paper presents the study on heat evolution of high volume fly-ash concrete. The study carried by measuring the temperature increase in the concrete under adiabatic curing condition, in this context the investigation was carried with the comparison of temperature rise in ordinary Portland cement concrete with the high volume fly ash concrete of maximum replacement of fly ash of $70 \%$ by weight of cement. The experimental results shows the characteristics heat evolution of fly ash concrete was found to be directly depended on the replacement of fly ash and dosage of superplasticizer to maintain workability, and also found that higher the replacement level of fly ash, the lower the temperature rise.

Hussein. M. et al. 2019 [14]. The paper presents the study on residual compressive strength of high strength concrete exposed to elevated temperature, the study represents the behavior of normal strength concrete high strength concrete when exposed to temperature. Here the predictive models are developed for NSC and HSC subjected to elevated temperature the relationships were obtained for compressive strength behavior , and regression models are developed for the prediction of residual compressive strength of HSC after being exposed to elevated temperature. From the experimental results found that the regression models propose single formula for whole range of elevated temperature, and the proposed models are applicable for high strength plain concrete produced using OPC and mineral additives such as fly ash or silica fume not exceeding $15 \%$ by weight of the cement. The use of proposed models should be restricted to HSC of compressive strength up to $100 \mathrm{Mpa}$.

Poonkuzhali.R. et.al. 2016 [15]. The research undertakes the experimental investigation on high volume fly ash concrete using manufactured sand. In this concrete of M40 grade is prepared with replacement of cement with high volume of fly ash in various proportions i.e. 
$0 \%, 30 \%, 40 \%, \& 50 \%$ respectively and river sand is replaced completely by manufactured sand as fine aggregate and the mechanical property as compressive strength of the concrete mix is tested. The test results shows that compressive strength of the concrete using manufactured sand as fine aggregate decreases with the increase in the replacement of cement by fly ash for early age of 14days.

A. Ferhat Bingol et al. 2008[16]. Studied the Effect of elevated temperatures and cooling regimes on normal strength concrete, in this paper the normal strength concrete of grade $\mathrm{C} 20$ \& $\mathrm{C} 35$ are designed and tested for mechanical properties and elevated temperature ranging $50^{\circ} \mathrm{C}-700^{\circ} \mathrm{C}$. Here the specimens are cured \& cooled in two conditions air and water then the results are compared. From the tests it is observed that in the range of $50-100^{\circ} \mathrm{C}$ increase in strength was observed in $\mathrm{C} 20$ and for $\mathrm{C} 30$ it is decreased, further increase in exposed temperature causes concrete to gradually lose its mechanical strength, also seen that strength loss was more in water-cooled specimen i.e. $80 \%$ and for air cooled specimens it is $30 \%$. No explosive spalling was observed during the tests. But insignificant crumbling was observed on the specimens heated over 500 ${ }^{0} \mathrm{C}$.

Siva Kishore Ikkurthi.et.el. 2017 [17]. The experiment is carried on comparative study on compressive strength of fly ash concrete, the paper studied the substitution of cement with varying amount of fly ash for different grades of concrete. The compressive and flexural strength of different grades of concretes are tested for varying percentage of fly ash replacement. The tests carried on fresh concrete shows improved workability by the addition of fly ash. And observed that the compressive strength of concrete will decreases with the increase of fly ash and the flexural strength of concrete is also reduced with increase in fly ash content.

Dr.R.R.Singh et.al. 2014[18]. Study on High Volume Fly Ash Concrete, In this paper, a brief review is presented on the theory and the design of M40 concrete mixture containing $28 \%, 50 \%, 70 \%$ fly ash by mass of cementitious material. The compressive strength of 3, 7 and 28 days and flexural strength of 28 and 56 days of $28 \%, 50 \%$ and $70 \%$ fly ash content M40 concrete cubes and beam sample respectively are compared, the cost comparison of the different grades of fly ash concrete and normal concretes is done. The investigation results shows The compressive and flexural strength of M40 concrete at $50 \%$ fly ash replacement by the mass of cement are acceptable, and therefore can be used in construction practice. The results obtained of M40 for 70\% Fly Ash content are not satisfactory or of the level of M40 grade of concrete. And the cost of M40 concrete at 50\% and 70\% Fly Ash content is less than M25 concrete at 28\% Fly Ash content.

Daniel .y.kong et.al.2019 [19] paper presents the result of a study on elevated temperature on geopolymer paste, mortar and concrete, the concrete is made using fly ash a precursor. Various experimental parameters gave been examined, such as specimen sizing, aggregate sizing, aggregate type and superplsticizer type. From the study identifies the specimen size and aggregate size as the two main factors that governs geopolymer behavior at elevated temperature, here the mix is designed and specimens are casted and each type of mix is tested for 3-days compressive strength, the test results shows the aggregate size larger than $10 \mathrm{~mm}$ resulted in good strength performance in both ambient and elevated temperature and the strength loss in geopolymer concrete at elevated temperature is attributed to the thermal mismatch between the geopolymer matrix and the aggregate.

Wei Wang et.al. 2017 [20] studied An investigation on thermal conductivity of fly ash concrete after elevated temperature exposure. In this paper, the influence of high temperature and micro-environment relative humidity on the thermal conductivity of fly ash concrete were investigated, In this paper, the influence of high temperature and micro-environment relative humidity on the thermal conductivity of fly ash concrete were investigated. The results showed that after exposed to high temperature, the compressive strength and thermal conductivity of both ordinary concrete and fly ash concrete were markedly reduced, and when the specimens were subjected to $550 \mathrm{C}$, the compressive strength reduced about $26 \%$. With an increase in micro-environment relative humidity, the thermal conductivity of both ordinary concrete and fly ash concrete were increased and when the relative humidity reached $100 \%$, the thermal conductivity increased about $22 \%$. Under same conditions, the thermal conductivity of fly ash concrete with $30 \%$ fly ash replacement was lower than that of ordinary concrete.

Alaa M.Rashad. 2014 [21] Investigated An exploratory study on high-volume fly ash concrete incorporating silica fume subjected to thermal loads. Right now, has been incompletely supplanted with a Class F fly debris (FA) at a degree of $70 \%$ to deliver high-volume fly debris (HVFA) concrete (F70). F70 was adjusted by halfway supplanting FA with silica seethe (SF) at levels of $10 \%$ and $20 \%$, by weight. All HVFA solid sorts were contrasted with the perfect Portland concrete (PC) concrete. Subsequent to relieving, the examples were presented to raised temperatures going from $4000 \mathrm{C}$ to 1000 0C with an interim of 200 0C. Weight and compressive quality when terminating have been altogether investigated. The different deterioration stages framed were recognized utilizing $\mathrm{X}$ beam diffraction (XRD) and filtering electron microscopy (SEM). From trial results it was accounted for that, All sorts of HVFA cements indicated better execution after various warmth medicines than that of the flawless PC concrete. Concrete indicated a decrease in its unique quality in the wake of being presented to $4000 \mathrm{Cand} 600$ 0C. Then again, a wide range of HVFA cements indicated an expansion in their unique quality and the F70 displayed the most noteworthy relative quality. The consideration of SF indicated higher leftover quality than F70 concrete at 400 0Cand 600 0C. Then again, F70 concrete indicated higher leftover quality at $8000 \mathrm{C}$ and $10000 \mathrm{C}$. 
Hosam.El_Din H. Seleem. 2010[22] . Completed investigation on Effect of elevated temperature on physico-mechanical properties of blended cement concrete cement. Through this work, the impact of various types of pozzolana on the fire resistive properties of concrete was contemplated. Four kinds of pozzolana were consolidated into the solid blends, for example met kaolin (MK), silica smolder (SF), fly debris (FA), and ground granulated impact heater slag (GGBS). Each of the utilized pozzolana was utilized in two proportions: $10 \%$ and $20 \%$, either as concrete substitution or as an expansion without influencing the concrete substance. The test outcomes illustrate, Upon warming to $2000 \mathrm{C}$, it was noticed that the compressive quality of all blends increments over the 28days quality of the comparing blends and the Heating up to 600 0C-800 0C caused a huge decrease in quality of all blends. The held quality proportion of the control blend dropped to $32 \%$. The pozzolana-blends had a superior quality retention ratios; up to $41 \%, 41 \%, 43 \%$, and $36 \%$ relating to the work of silica seethe, meta kaolin, fly debris, and GGBS individually. From all the blends the held (lingering) compressive quality estimations of the silica seethe blends are the most noteworthy.

Y.H. Mugahed Amran et.al [23]. Examined Performance examination of high-proportion Saudi-fly ash based cement. This examination presents the discoveries of utilizing various volumes of SFA with variable extents (i.e., $0 \%, 10 \%, 20 \%, 30 \%, 40 \%$, and half). Test tests were performed to examine the properties of SFA-based cement, including droop test, air content, setting times, warm profile, explicit gravity, sifter degree, flexural quality, compressive quality, rigidity, wear profundity, protection from scraped area, and versatility modulus, at various time interims for one year. Be that as it may, the solidified quality properties and protection from scraped area displayed unremitting and significant upgrade at 56 days and as long as one year, which is commonly owing to the pozzolanic response of SFA. Accordingly, all qualities expanded when warm warmth diminished, and test results demonstrate that SFA can conceivably substitute concrete in concrete by up to half for the creation of auxiliary solid components in the development business. This exploration presents the discoveries of including high volumes of SFA at various extents (i.e., $0 \%, 10 \%, 20 \%, 30 \%, 40 \%$, and half). The qualities of the SFA-based cement with $10 \%$, $20 \%, 30 \%, 40 \%$, and half SFA substance following 28 days were seen as sufficient for the manufacture of basic solid components, and the protection from scraped area improved with the addition in age for all SFA-based solid mortars.

H.Suleyman Gokce 2020 [24]. concentrated High temperature resistance of boron active belite cement mortars containing fly ash. In the examination, neutron lessening component of boron dynamic belite concretes at different fly debris presentation was hypothetically uncovered by contrasting and an elective low warmth concrete (Portland composite concrete). High temperature opposition of the concretes with and without fly debris presentation was resolved on standard mortar crystals at raised temperatures up to $900{ }^{\circ} \mathrm{C}$ concerning compressive quality and flexural quality. Neutron protecting execution of boron dynamic belite concrete was discovered right around multiple times higher than Portland composite concrete. Fly debris presentation essentially diminished the neutron weakening variable of boron dynamic belite concrete. High temperature opposition of boron dynamic belite concrete mortar was discovered lower than that of Portland composite concrete mortar at $700{ }^{\circ} \mathrm{C}$ at later relieving time. $10 \%$ fly debris presentation improved the high temperature execution of boron dynamic belite concrete mortar presented to $900{ }^{\circ} \mathrm{C}$. Lingering compressive quality estimations ofthe mortars containing fly debris were somewhere in the range of $16 \%$ and $28 \%$ in the wake of uncovering $900{ }^{\circ} \mathrm{C}$.

Yu Zhu,et al. 2012[25]. Researched the Use of slag to improve mechanical properties of designed cementitious composites (ECCs) with high volumes of fly debris, The reason for this paper is to build up a sort of green ECC with high tractable malleability and sufficient framework quality, particularly at early age. A progression of examinations has done to assess mechanical properties and drying shrinkage of ECC with $70 \%$ blend mineral admixtures of FA and ground granulated impact heater slag (SL). The exploratory outcomes show that ECC with mix mineral admixtures can accomplish strain solidifying conduct, malleable limit of ECC can be over $2.5 \%$ at 90 days. Then, contrasted with ECC just with FA, SL and FA can viably increment compressive quality of ECC, particularly at early age. Joining SL into framework can marginally increment drying shrinkage of ECC. Be that as it may, among four ECC blends, ECC with $30 \%$ SL and $40 \%$ FA presents the least drying shrinkage at later ages.

\section{MAJOR FINDING FROM THE LITERATURE REVIEW}

In case of high volume fly ash blended concrete an increasing trend of compressive strength, flexural strength and split tensile strength was observed from 28 days to 56 days curing period. And the modulus of elasticity increases from 28days to 365 days. [2],[5],[6],[8],[10],[12],[17].

$>$ The colour of HVFA concrete was found to be influenced by the intensity of temperature exposure and the deterioration of HVFA concrete increased with an increase in temperature. [1],[2],[5],[6]

$>$ Fly ash blended concrete perform better than ordinary concrete when exposed to high temperature.

$>$ Increase in fly ash content in concrete increases the setting time, decreases the unit weight and the workability is also improved when a more suitable superplasticizer is used.[8],[17].

$>$ Observed that $0.25 \%$ of natural admixture dosage can be considered as optimum dosage for fly ash blended concrete. [10]. 
Due to the increasing trend of flexural strength for later age, it can be used for pavement construction, and due to higher strength there will be reduction in thickness of pavement and there will be reduction in cost and hence it is economical. [11],[17].

Under elevated temperature smaller sized aggregate $(<10 \mathrm{~mm})$ promote spalling and extensive cracking and concrete containing larger aggregates $(>10 \mathrm{~mm})$ are stable in elevated temperature. [19].

$>$ Low compressive strength of HVFA concrete can be improved by replacing part of fly ash with $10 \%$ or $20 \%$ of silica fume. [21],[22],[25].

\section{CONCLUSION}

From the above literature review we conclude that high volume fly ash concrete shows good fire resistance performance for elevated temperature up to $600^{\circ} \mathrm{c}$, and hence HVFA can be used in the field where thermal cracking due to heat of hydration should be avoided such as dams, large foundation buildings etc. Also concludes that the increase in fly ash content in concrete above $50 \%$ the mechanical properties such as flexural strength, compressive, split tensile strength and modulus of elasticity shows the decreasing trend in strength in the early age for 7 days and 14 days, at the later age for 28days to 90 days the strength properties increases. the loss in weight and change in colour of the HVFA concrete is observed when exposed to high temperature. Through the study it has seen that the concrete has very less thermal conductivity and it is concluded that higher the replacement level of fly ash , the lower the temperature rise in concrete

\section{REFERENCES}

[1]. M.S.Khan and H.Abbas 2014 "Effect of Elevated Temperature on the Behavior of High Volume Fly Ash Concrete". KSCE journal of civil engineering.

[2]. Mahesh Tailam, June 2018. "Temperature studies on fly ash based concrete." International Journal For Technological Research In Engineering Volume 5, Issue 10, June-2018.

[3]. Jagathkumari.et.al. 2017 "Effect of Elevated Temperatures on Compressive Strength of High Volume Fly Ash Concrete" International Journal of Scientific Engineering and Research.

[4]. M.S. Krishna Hygrive January 2017 "Effect of Elevated Temperature on the Behavior of High Volume Fly Ash Concrete.'International Journal of Civil Engineering and Technology .

[5]. B. H. Manjunath.et.al. December 2016 "High volume high performance fly ash concrete mix design for pavement overlay for sustainable development." International Journal of Civil Engineering and Technology (IJCIET) Volume 7, Issue 6.

[6]. Dr.K.V.Ramesh, Dharma.et.el.2016 "A Study on High Volume Fly Ash Concrete Exposed To Elevated Temperatures." American Journal of Engineering Research (AJER) Volume-5, Issue-11, pp-227-238.
[7]. Huai-Shuai shang and Ting-Hua Yi March 2013 "Behavior of HPC with Fly Ash after Elevated Temperature." Advances in Materials Science and Engineering,volume 2013.

[8]. Chung-Ho Huang. May 2013. "Mix proportions and mechanical properties of concrete containing very high-volume of Class F fly ash." Construction and Building Materials.

[9]. Metin Husem. "The effects of high temperature on compressive and flexural strengths of ordinary and high-performance concrete." Fire Safety Journal 41 (2006).

[10]. T.S. Ramesh Babu and D. Neeraja October 2016. “A experimental study of natural admixture effect on conventional concrete and high volume class F fly ash blended concrete." Case Studies in Construction Materials.

[11]. Nikhil.T.R. November 2019 "Use of High Volume Fly ash in Concrete Pavements For Sustainable Development."International Journal of Scientific Research. Volume : 3 | Issue : 1 | January 2014.

[12]. Mr. A. Gunaseela et.al 2016. "Experimental Study on Performance of High Volume Fly Ash Concrete." IJIRST -International Journal for Innovative Research in Science \& Technology| Volume 2| Issue 12 | May 2016.

[13]. Cengiz Duran Atis. December 2001. "Heat evolution of high-volume fly ash concrete." Cement and Concrete Research 32 (2002).

[14]. Hussein. M. et al. 2019 " The paper presents the study on residual compressive strength of high strength concrete exposed to elevated temperature." Advances in material sciences and Engineering, Volume 2019.

[15]. Poonkuzhali. R February 2016 "Experimental Investigation on High Volume Fly Ash Concrete using Manufactured Sand." International Journal of Engineering Research \& Technology (IJERT),Vol. 5 Issue 02.

[16]. Ferhat Bingol. November 2008 "Effect of elevated temperatures and cooling regimes on normal strength concrete." Fire and materials.

[17]. Siva Kishore et.al. 2017 " comparative study on compressive strength of fly ash concrete." International Journal of Civil Engineering and Technology (IJCIET) Volume 8, Issue 4, April 2017.

[18]. Dr. R.R Singh. 2014. " High Volume Fly Ash Concrete." International journal of science research,Volume:3|Issue:6|June2014.

[19]. Daniel .y.kong et.al. October 2019 . " Effect of elevated temperature on geopolymer paste, mortar and concrete." Cement and Concrete research.

[20]. Wei Wang, Caifeng Lu 2017 "An investigation on thermal conductivity of fly ash concrete after elevated temperature exposure." Construction and Building Materials.

[21]. Ala.M.Rashad . September "An exploratory study on high-volume fly ash concrete incorporating silica fume subjected to thermal loads." Journal of Cleaner Production. 
[22]. Hosam.El_Din H. Seleem. August 2010 "Effect of elevated temperature on physico-mechanical properties of blended cement concrete." Construction and Building Materials.

[23]. Y.H. Mugahed Amran. 2020 "Performance investigation of high-proportion Saudi-fly-ash-based concrete." Results in Engineering.

[24]. H.Suleyman Gokce, November 2018. "High temperature resistance of boron active belite cement mortars containing fly ash." Journal of Cleaner Production.

[25]. Yu Zhu, and Yingzi Yang. August 2012" Use of slag to improve mechanical properties of engineered cementitious composites (ECCs) with high volumes of fly ash." Construction and Building Materials. 